\title{
Uganda's rangeland policy: intentions, consequences and opportunities
}

\author{
Patrick Byakagaba ${ }^{1 *}$, Anthony Egeru $^{1,2}$, Bernard Barasa $^{1}$ and David D. Briske ${ }^{3}$
}

\begin{abstract}
This paper analyses Uganda's rangeland policies and their ecological and socio-economic consequences, beginning in pre-colonial times. The paper interrogates what informed these policies, their objectives and outcomes that have been realized. Policy actions are recommended to correct the deficiencies identified in the analysis. This analysis shows that policies were based on western European resource management, classical rangeland ecological and economic theory and marginalization narratives, rather than the socio-ecological realities of Uganda's rangelands. The unique attributes of Uganda's rangelands were largely unrecognized. Consequently, pastoralists, dependent on the rangeland resources and ecosystem services, were displaced and exposed to incremental risks, poverty and a breakdown of social networks and safety nets as well as decline in rangeland productivity. In the rangelands of north-eastern Uganda for example, the inflexibility and immobility and forms of exploitation dictated to the Karimojong pastoralists led to increased soil erosion and decline in land productivity. Similarly, with increased parcelization, individualization and sedentarization in central and south-western Uganda, pastoral communities became impoverished as rangeland resources became increasingly limited. This increased their exposure to the vagaries of extreme events such as droughts, floods and disease outbreaks, thereby increasing livestock mortality and recurrent food insecurity. Expansion of competing land uses has reduced the net availability of rangeland resources, often with the support of external incentives. Current policies promoting fire exclusion have led to increased bush encroachment, while other policies have undermined the centrality of commons' governance practices and institutions. Uganda's land use policies ought to emphasize a more balanced socio-ecological perspective (ensuring net gain especially in the interaction of resource use between humans and the environment) that supports the functionality and productivity of rangeland ecosystems and their ability to deliver socioeconomically important ecosystem services and address human needs. This can be through promotion of common property and consolidation of land for optimal utilization of ecological heterogeneity and enhancement of resilience. Mapping of transhumance corridors to determine ways through which mobility can increase herds' access to forage and water between and within years will be equally important to enhance pastoralists' resilience. Policy actions that provide payments for conservation stewardship of rangelands should be considered to incentivize land owners to maintain their land as rangelands. Assessment is required of the ecological and social impacts of fire, in order to determine optimal fire regimes and amendment of laws that ban the use of fires, so as to promote prescribed burning in rangelands. Achieving all these will require reforms that clearly delineate policy and legal frameworks for sustainable rangeland use and management.
\end{abstract}

Keywords: Colonial, Disruption, Encroachment, Pastoralists, Regulations, Uganda

\footnotetext{
* Correspondence: byakagaba@caes.mak.ac.ug

1 Department of Environmental Management, Makerere University, P.O Box

7062, Kampala, Uganda

Full list of author information is available at the end of the article
} 


\section{Introduction}

Rangelands cover $44 \%$ of Uganda's total land area, sustaining $80 \%$ of the national livestock herd and $90 \%$ of the cattle (Government of Uganda 2014). Most of the rangelands in Uganda are dominated by pastoralists, and approximately $64 \%$ of them (22\% of Uganda's human population) are categorized as poor (Kirkbride and Grahn 2008, Ministry of Agriculture Animal Industry and Fisheries Uganda et al. 2010). Drought and heat-induced livestock mortality has increased in Uganda due to starvation and lack of water; this causes significant economic losses, and negatively impacts on livelihoods of pastoral communities and increases their impoverishment (Stites et al. 2010, Mwaura and Katunze 2014). Increased bush expansion in Ugandan rangelands by several native species, including Acacia (Vachellia) hockii De Wild and Lantana camara L., and increasing non-palatable grass species such as Cymbopogon afronardus Stapf have contributed to a decline in rangeland productivity, especially for grazers (Mugasi et al. 2000, Oba et al. 2008, Roschinsky et al. 2012). We posit that many of these aforementioned challenges can be traced back to land use and economic policies originating from the colonial era, which generally focused on the production efficiency of a small number of provisioning ecosystem services and failed to account for regulatory, cultural and supporting ecosystem services from rangelands (Muhereza 2001, Pulkol 1994, Kisamba-Mugerwa 1992).

The first region of Uganda where the government intentionally introduced a new land tenure policy was in north-eastern Uganda, commonly referred to as the Karamoja sub-region. This area borders Kenya and (now) South Sudan and currently has $19.8 \%$ (2.3 million) of the cattle herd in Uganda (Government of Uganda 2008). The government actions in this region can be summarized in six phases which occurred during the colonial and postindependence era: (i) 1898 to 1920 was the period when the British colonial administration was extending their rule into new areas beyond central Uganda where they first settled. In Karamoja sub-region, they set up new colonial administrative systems that interfered with the traditional governance system of the pastoralists that lived in this area. This was the period when pastoralism was first discouraged in Uganda through orders of the administrators and their agents. Pastoralism was perceived to be archaic and backward. The colonial administrators regarded pastoralism as a way of life that made it difficult to have control over the communities in areas where it was practiced. (ii) 1920 to 1940 was the transfer of 1,500 to 2,000 sq. miles of land from the Chemerongit Hills to the Kamyangareng River to the colonial administration in Kenya and the expansion of the boundaries of Teso region (a region occupied by another ethnic group in north-eastern Uganda that practiced agro-pastoralism), (iii) the 1930s to late 1940s saw the extension of colonial administration and church missions with large tracts of land being appropriated with a simple declaration as 'Crown land', (iv) early 1950s to late 1950s witnessed the gazetting (designation) of several tracts of land (486 sq. miles) as game reserves, (v) the 1960s was characterized by individuals, administration officials and local petty bourgeois fencing off land for personal enrichment, and (vi) the 1980s represented a period when several development assistance initiatives were introduced, such as promotion of crop cultivation through provision of agricultural subsidies in the form of seed and tractors to address food insecurity and encouragement of pastoralists to live a more sedentary lifestyle. These initiatives were brought by the Ugandan government with support from multilateral donor agencies, ostensibly to enhance economic productivity of this region and the wellbeing of the pastoral communities (Barber 1962, Egeru et al. 2014, Mamdani 1982, Nakalembe et al. 2017, Quam 1978).

The changes introduced by the colonial administration as observed in Karamoja sub-region were also apparent in other parts of Uganda where rangelands were predominant. In central to south-western Uganda, land appropriation by introduction of new land ownership modalities orchestrated transformations in land relations. For example, the British entered into an agreement with Buganda (a region within central Uganda) in 1900 to create a new land tenure system in which former customary land vested in their traditional leader (addressed as Kabaka in the local language) was allocated in parcels of miles to individuals who had worked for the British as collaborators in their expansion of colonial rule in the rest of Uganda. This agreement created the 'mailo' (mile in Uganda's dialects), freehold and crown land tenure system (Okuku 2006). These changes turned individuals who previously had permanent inheritable rights into tenants by sufferance who had to pay rent to the new registered owners. The post-independence governments of Uganda have since then continued to perpetuate these colonial policies by various means.

In this paper, we interrogate Uganda's land use and economic policies from the colonial period (1890s to 1962) to the current administration by analysing what informed them, their originally intended objectives and the actual outcomes and consequences that have been realized in relation to the functioning of contemporary rangeland systems.

We further assess the theory postulating that characterization of policy problems is a product of a political process, other than objectivity (Hoornbeek and Peters 2017) in relation to Uganda's policies relevant to rangelands. We suggest policy recommendations to address the deficiencies that have been identified to promote a more inclusive valuation of Uganda's rangeland resources and the pastoralists that utilize them. The paper is based on an assessment of relevant empirical studies that have been published and unpublished. 


\section{Study area}

Uganda is a landlocked country located in eatern Africa and it is bordered by South Sudan in the north, Kenya in the east, Tanzania and Rwanda in the south and Democractic republic of Congo in the west. It covers an area of 241,038 square kilometres. It experiences tropical climate with temperatures ranging between 18-28 degree centigrade. Uganda became a British protectorate in 1894 and attained her independence in 1962. It has since then had various leaders who ascended to power through elections, coups and violence. It is currently governed under the multi-party dispensation with regular elections held every five years. The parliament is dominated by the ruling party called the National Resistance Movement.

According to the Uganda National population and housing census report of 2014, the total population was 34.6 million people in 2014, with children below 18 years constituting $55 \%$ of the population. Most of the population is rural-based and derive their livelihood from agriculture including crop and livestock production.

According to the National Development Plan ii, approximately 72 percent of the population is employed in agriculture.

Livestock production is mainly carriedout in districts commonly known as the "cattle corridor" districts because of their characteristic conditions for cattle production. This area extends from the districts bordering Tanzania and Rwanda in the south, through central Uganda to the north-east in districts bordering Kenya and South Sudan. The National Livestock Census Report of 2008 indicates that most households (92.7\%) that have cattle mainly keep indigenous herds. The average average growth domestic product growth between 20102015 was $5.5 \%$.

\section{Chronology of land use policies impacting rangelands and pastoralists \\ Historical perspective on land and rangeland tenure system in Uganda}

In the pre-colonial era, rangelands were traditionally managed under common property regimes based on customary institutions which provided for all members to enjoy use rights, while transfer was strictly through inheritance of use rights, but not ownership (Okuku 2006). Rangeland resources were managed as commons using customary authority systems that determined access and use. Use rights were generally equal within kinship or territorial groups, while outsiders were excluded except through negotiations of elders. The customary authorities ensured that grazing practices did not harm rangeland resources through the use of sanctions for those who did not adhere to the expected norms and practices (Kisamba-Mugerwa 1992). For instance, all pastoralists were expected to follow the established grazing patterns, including the exclusion of livestock grazing on dry season reserves during the wet season (Oba et al. 2008).

Customary grazing practices included following herd movement routes and customary land use practices that prevented the over use of rangeland resources such as regular assessment by range scouts (Oba 2012). Herd movement and stocking capacity was based on detailed range assessment by the range scouts who would evaluate both the quality and quantity of the available forage, range condition and water availability and quality which ensured sustainable use of rangelands (Kyagaba 2004, Oba 2012).

Prior to the onset of colonial administration and the crafting of Uganda as a nation, various tribal communities managed land ownership, use and governance in varying forms. In central Uganda for example, land formed the cornerstone of identity and was nominally controlled by the King (Kabaka) in trust for his subjects while individual plots were conferred upon the peasants by local chiefs (Green 2006). In Ankole region, in western Uganda, a delicate balance on land existed between the Bairu (ethnic group that predominantly practiced crop production) and Bahima (ethnic group involved mainly in livestock production up to today) with the Bahima having maintained a privileged hegemonic state over land and resources (Doornbos 1975). Access to crucial pastoral resources in parts of Ankole rangelands, especially in Nshara and lakes Mburo, Kachera and Kigambira, was determined through express permission of the King, traditionally known as Omugabe of Ankole kingdom. Meanwhile, in northern Uganda, in parts of Lango and Acholi sub-regions, there was no landlessness since land was communally owned through the clan system with no land transactions allowed (Tosh 1978).

Most local rangeland communities in Uganda had a hierarchical system of elders whose main responsibility was determining rangeland use patterns and enforcing traditional norms and values regarding rangeland use and livestock production, to ensure that range productivity was sustained (Rugadya and Kamusiime 2013). Clans had informal mechanisms through which they would access rangelands that were under the jurisdiction of other clans and this prevented land conflicts and ensured rational movement of livestock according to the seasons and suitability of the range (Ocan and Ocan 1994).

Arrival of British colonial administrators in the 1890s and the eventual declaration of Uganda as a British protectorate in 1894 changed the land tenure system in Uganda. Private ownership was promoted through signing of agreements between the colonial administrators of Great Britain and traditional leaders of the existing kingdoms in 
central and western Uganda. The Buganda Agreement of 1900 in central Uganda, the 1900 Toro Agreement, and the 1901 Ankole Agreement in western Uganda, respectively, were the major agreements that first introduced individualization of land in Uganda (Beyaraza 2004).

Individualization of land was highly regarded by the colonial administrators because of the prejudice they held towards the customary communal land system that was predominant in Uganda.

They believed that customary communal tenure system was prone to insecurity and that it did not provide an incentive to invest in land or implement improvements due to inadequate tenure security (Brock 1969, Lastarria-Cornhiel 2003). It was further argued that communal tenure was a disincentive to long-term agricultural investments which promoted increased export of raw materials to the growing industry in Great Britain, and the collection of taxes from the people of Uganda. Individual land ownership was further galvanized by a policy recommendation of the Royal Commission of Great Britain in 1955 that required Uganda to pursue a land tenure system that provides for individualization of land (Kisamba-Mugerwa 1992). Table 1 shows the key features of land governance and their impacts on rangeland use and pastoralism.

\section{Recent policy on land and rangeland tenure}

Colonial perceptions of land tenure were wholly embraced by post-independence governments; this included perceiving rangelands as idle and unproductive under the communal land tenure system, just like their predecessors had assumed. The practice of promoting individualization of land in rangeland areas became dominant to the extent that most of the rangelands in central, south and western Uganda were demarcated into blocks of square miles (ranches) and allocated free of any payments to individuals who qualified to manage them for commercial beef and milk production, based on government's predetermined standards and allocations (Kisamba-Mugerwa 1995). These predetermined allocations and standards were based on modernization narratives which were inconsistent with the cultural norms and livestock production objectives of the indigenous people (Msuya 2015).

The national post-independence governments initially established five regional ranching schemes: Ankole (west); Masaka, Singo and Buruli (central) and Bunyoro (west) on extensive pastoral lands, and leased them to influential politicians and cooperative societies of political elites (Doornbos and Lofchie 1970, Mugerwa and Zziwa 2014, Pulkol 1994). The beneficiaries were regarded as "progressive farmers" who were expected to manage these ranches at a commercial scale to produce meat and milk so that Uganda would reduce their importation and eventually export these products to generate revenue (Pulkol 1994).
The initial processes of establishing these ranches were implemented by colonial administrators in the 1950s.

Land administration as prescribed in the Land Act, 1998, and the Uganda National Land Policy, 2013, have strengthened individualization of land in most rangeland regions through deliberate interventions of registering individual freeholds and leases and further sub-dividing ranches into smaller blocks in an effort to commercialize and modernize the livestock industry (Byenkya et al. 2014). Communal ownership of land that is practiced by pastoralists is still perceived as inefficient and backward by technocrats. Proponents of individualization of land contend that under communal ownership of land, costs and benefits of individual action do not accrue to the decision-making unit, investments are biased towards short-term projects because property rights are not well defined, and land transactions are limited because of uncertain ownership rights (Platteau 1996).

Critics of communal land ownership also contend that it promotes widespread land fragmentation because it requires availing land to all heirs of the deceases and others with customary rights, thus leading to uneconomic land holdings, decreased land productivity and discouraging a vibrant land market (Kalabamu 2000). In contrast, individualization of rangelands is assumed to promote proper management of livestock herds in relation to forage availability, thus increasing both economic production and resource sustainability. This interpretation has been further strengthened by economic development pressure exerted by multi-lateral lending agencies and international donor organizations to maximize agriculture's contribution for social wellbeing (Barrows and Roth 1990, Pearson and Muchunguzi 2011).

\section{Sedentarization of pastoralists}

Pastoralists' sedentarization is the process of settling formerly nomadic populations and their livestock into non-mobile communities (Fratkin et al. 2004). The policy trajectory of the colonial and post-independence governments in Uganda is characterized by sedentarization of pastoralists (Kisamba-Mugerwa et al. 2006, Knighton 2006). This has been done through both implicit and explicit policy actions to modernize livestock production, achieve sustainability of rangelands and secure the livelihoods of pastoralists through sedentarization. Pastoralism is often seen as "backward" while sedentarization is perceived as a panacea to perceived problems of pastoralist livestock management in rangelands (Wurzinger et al. 2009).

Sedentarization of pastoralists started during the colonial administration and was sustained by the post-independence governments when the rangelands of south-western Uganda in Mbarara and other parts of the "cattle corridor" (dry belt of Uganda well-known for cattle production) were demarcated and allocated to individuals as ranches. It was mainly the elite pastoralists who were privileged in the 
Table 1 Key phases in the evolution of land use policies and laws in Uganda

\begin{tabular}{|c|c|c|}
\hline Phase & Key features of the phase & Source \\
\hline Pre-colonial(before1894) & $\begin{array}{l}\text { - Land tenure was based on the customary systems, in both the sedentary and } \\
\text { pastoral communities } \\
\text { - Three broad customary land tenure systems were in place; communal/tribal, } \\
\text { clan tenure, and nomadic tenure } \\
\text { - In central Uganda (Buganda) land was controlled and managed by the } \\
\text { Kabaka (King) as a trustee who would allocate land anywhere to any clan or } \\
\text { group of individuals } \\
\text { - In pastoral communities (mainly in the semi-arid areas) that practiced } \\
\text { transhumance livestock management, access to land was based on clans } \\
\text { and household reciprocal agreements with other clans and neighbours } \\
\text { especially those occupying the dry season grazing areas. } \\
\text { - Grazing rights among pastoral communities were vested in the entire members } \\
\text { of the tribe with no specific rights vested in individuals } \\
\text { - The social, political and resource boundaries were flexible and negotiable in areas } \\
\text { covered by rangelands } \\
\text { - The local kings and chiefs had no rights to sell but held land in trust of their } \\
\text { people in all parts of Uganda that had their land vested in them }\end{array}$ & $\begin{array}{l}\text { Lastarria-Cornhiel (2003). } \\
\text { Green (2006) } \\
\text { Wabineno-Oryema (2015) }\end{array}$ \\
\hline Colonial phase (1894-1961) & $\begin{array}{l}\text { - Colonial powers and administrators introduced a new system of land } \\
\text { administration with four different land tenure regimes: (i) mailo, (ii) freehold, } \\
\text { (iii) leasehold, and (iv) crown land (under Queen of England). } \\
\text { - Initial attempts made to formalize land rights and ownership-the means to } \\
\text { holding land. } \\
\text { - Land agreements between the British and Kingdoms such as the } 1900 \text { Buganda } \\
\text { agreement, 1901, Ankole agreement and Tooro agreements were implimented } \\
\text { - For the first time, individuals who occupied land declared as 'freehold and leasehold' } \\
\text { were prone to be evicted without asking for their permission } \\
\text { - Payments for use of land including rangelands in form of rent became established } \\
\text { especially in Ankole (south western Uganda), Tooro (Mid-western Uganda) and } \\
\text { Buganda (central Uganda) with the various laws established such as the } 1900 \\
\text { Toro Agreement and } 1901 \text { Ankole Agreement }\end{array}$ & $\begin{array}{l}\text { Wabineno-Oryema (2015) } \\
\text { Rugadya and Kamusiime (2013) }\end{array}$ \\
\hline $\begin{array}{l}\text { From independence to early } \\
\text { reform periods (1962-1985) }\end{array}$ & $\begin{array}{l}\text { - Crown land became designated Public land under the Public Land Act of } 1962 \\
\text { - Insecurity of land tenure increased as the Public Land Act, 1962, made it possible } \\
\text { to easily offer Freehold and Leasehold to individuals even in the customary land } \\
\text { tenure systems. } \\
\text { - Public lands Act, } 1969 \text { put a cap at } 500 \text { acres for any land acquisition unless } \\
\text { authorized by a Minister in charge of land } \\
\text { - The } 1975 \text { Land Reform Decree (LRD) was passed by the then President of Uganda } \\
\text { (Idi Amin Dada). All land was nationalized and vested in the Uganda land } \\
\text { commission for economic and social development } \\
\text { The Land Reform Decree of } 1975 \text { removed the recognition of pastoral communities } \\
\text { rights on land.This decree triggered the grabbing of grazing land by speculators } \\
\text { through long-termleaseholds, especially in the southwest region, thus } \\
\text { "progressive ranchers" fenced off the hitherto common access, grazing area, water } \\
\text { areas, cattle, and salt licks thus marginalizing pastoralists } \\
\text { - Subsidies were provided to ranch owners to implement modern methods of } \\
\text { cattle production }\end{array}$ & $\begin{array}{l}\text { Wabineno-Oryema (2015) } \\
\text { Beyaraza (2004) }\end{array}$ \\
\hline $\begin{array}{l}\text { From early reform to present } \\
\text { reform phase (1986-2016) }\end{array}$ & $\begin{array}{l}\text { - The } 1995 \text { Constitution of Uganda and the } 1998 \text { Land Act of Uganda were enacted } \\
\text { with a provision that all land belonged to the people of Uganda under four tenure } \\
\text { systems which include, "mailo" freehold, leasehold and customary. } \\
\text { - Individual ownership became more entrenched and evolution of a market of land } \\
\text { became more apparent. } \\
\text { - Customary land ownership/tenure became recoganised } \\
\text { - Land conflicts became intense especially in areas with heightened individualistion } \\
\text { of ownership. } \\
\text { - Partitioning of communal grazing lands into small ranches } \\
\text { - Fencing off most of the established ranches in an attempt to control grazing and } \\
\text { spread of livestock disease amongst animals on different ranches } \\
\text { - Land and Land use Policies have been formulated but implementation is not yet } \\
\text { fully underway } \\
\text { - Communal land is increasingly being registered fraudulently as freehold by local elites } \\
\text { especially in areas covered by rangelands }\end{array}$ & $\begin{array}{l}\text { Government of Uganda (1995) } \\
\text { Government of Uganda (1998) } \\
\text { Government of Uganda (2013) } \\
\text { Government of Uganda (2007) } \\
\text { Rugadya (1999) } \\
\text { Beyaraza (2004) } \\
\text { McAuslan (2013) }\end{array}$ \\
\hline
\end{tabular}

allocation. The pastoralists who did not acquire land during that allocation were displaced and had to search for pasture in other parts of Uganda outside their ancestral territory.
This often became a source of conflict between the "host" communities and the displaced pastoralists. The pastoral communities in south-western Uganda locally known as 
Bahima have been mobilized in the recent years to live a sedentary lifestyle in order to have access to education and increase productivity of their livestock (ibid).

Similarly, sedentarization of pastoralists in Karamoja sub-region (north-eastern Uganda) became prominent during the period when the region experienced insurgency due to cattle rustling among the local communities and those from neighbouring countries. The Government of Uganda coerced pastoralists to live in protected camps known as protected kraals, ostensibly to provide security (Filipová and Johanisova 2017). These camps were sustained even when the region was pacified, thus leaving vast pastoral land unutilized and susceptible to illegal acquisition by unscrupulous individuals, especially local elites who acted on their own behalf or as proxies of financially and politically connected people in the country. There is a possibility that they may convert the acquired land into ranches just like what happened in Ankole and Bunyoro (western Uganda), thus negatively impacting the pastoral communities.

The proponents of sedentarization have done this without considering the consequences. In 1961, the last year of British administration in Uganda, a committee composed of British administrators and Uganda's future political leaders being prepared to receive instruments of power from the British colonial administration at independence under the leadership of a Ugandan, was commissioned to carry out an enquiry on measures and strategies that needed to be implemented to maintain law and order in north eastern Uganda, focusing mainly on Karamoja which was inhabited by Karimojong pastoralists (Bataringaya 1961).

This committee recommended that the Karimojong pastoralists needed to be taught, induced and assisted to live a "settled" and "peaceful" life and the deployment of the army was necessary to implement the recommendations. ${ }^{1}$ The committee further recommended that the pastoralists in this sub-region are settled into arable areas so that more food crops could be introduced in their diet.

The colonial administration thus set up strategies to eliminate pastoralism and implement programs and provide social services for only sedentary people. This did not change with the post-independence governments (Otim 2004). Efforts were further made to settle pastoralists through imposition of boundaries, gazetting of land for game and forest reserves, restriction of movement to dry season grazing areas, forced de-stocking, marginalization of customary institutions and commons governance, and the intensification of sedentary farming (Nsamba 2013).

Uganda has ten national parks and ten wildlife reserves of which five of the parks are in former lands that were traditionally used for grazing by pastoralists; these include Lake Mburo, Murchison falls, Queen Elizabeth, Semuliki and Kidepo valley. All the ten wildlife reserves - which include Ajais, Bokora corridor, Bugungu, East Madi, Katonga, Kabwoya, Karuma, Kigezi, Kyambura, Lomunga, Matheniko, Pian-Upe and Toro-Semuliki (UWA 2013) - were traditionally grazing land (dominant vegetation is savanna grasslands and woodlands) available to pastoralists. Designation of these lands as protected areas for wildlife conservation as national parks or wildlife reserves is partly a cause of pastoralist sedentarization nin Uganda, because they are not allowed to graze in these lands by law, thus leaving them in limited land areas where pastoralism cannot be practiced (Emerton 1999, Mamdani 1982).

The intended objectives of sedentarization policies were greater economic productivity and minimization of environmental damage (Chapman and Kagaha 2009, Kirkbride and Grahn 2008, Nsamba 2013). The nongovernmental Organizations (NGOs) working in the semi-arid sub-regions of Uganda have furthered the transformation of rangelands through immense advocacy of the sedentary systems and crop cultivation as precepts for 'food security' (Egeru et al. 2015).

Executive statements and orders discouraging pastoralism are common phenomena in Uganda, and there are some latent considerations to enact laws that will criminalize movement of herds as traditionally practiced by pastoralists (Knighton 2006). Sedentarization of pastoralists is apparent in policy documents such as the first National Development Plan which mentions pastoralism as a livelihood strategy with many ills and thus needs to be addressed through alternative options that will encourage pastoralists to adopt a settled lifestyle (Government of Uganda 2010). Elimination of pastoralism has been considered a panacea for resolving food insecurity, environmental conservation, poor health and governance challenges in areas currently dominated by mobile pastoral communities in Uganda (Muhereza 2001).

\section{Rangeland conversion into other land uses}

Economic empowerment, improvement of household income through crop cultivation, ensuring food and energy security, and timber production, have been the underlying factors driving rangeland conversion in Uganda (Nakalembe et al. 2017, Zziwa et al. 2012). Rangelands in Uganda have been converted to other land uses partly because of government's policies emphasizing improved agricultural production. The most recent policy intervention is the Plan for Modernization of Agriculture which evolved into Prosperity for All and is currently known as Operation Wealth Creation (Joughin and Kjær 2010). This intervention has led to a phenomenon described by Egeru et al. (2014) as 'a chlorophyll syndrome' where politicians, technocrats and some non-state actors regard crop 
cultivation as a panacea to achieving household food security in marginalized areas. Grassland cover decreased by 9.2\% between 1990 and 2015 mainly due to agricultural expansion (Government of Uganda 2016).

The current government of Uganda has indirectly subsidized rangeland conversion by providing free planting materials and tractors to farmers to clear land and grow crops in rangelands. Agricultural conversion has also been promoted by local and international development organizations such as the United Nations Food and Agriculture Organization (FAO) and World Food Program (WFP) that provide farm equipment, seed and other agricultural inputs to local communities in rangeland regions, without any safeguards to conserve rangelands (Egeru et al. 2014).

These interventions provide incentives for conversion of rangelands into cropland. Section 47 of the National Environment Act, 1995, of Uganda provides for the sustainable management and use of rangelands, but it does not unequivocally restrict their conversion to other uses. There are no regulations to operationalize the intended objectives of this provision in the Act that would have probably minimized rangeland conversion into other uses as the spirit of the law suggests. The Land Act, 1998 which could have further provided guidance to this matter is silent on rangelands. Section 44 of the Land Act, 1998 does not mention rangelands as a category of environmentally sensitive areas that require regulation, further emphasizing the marginalization of rangelands in Uganda's legal framework.

The National Land Policy, 2013 (section 62, iii), provides for zoning to establish appropriate agro-ecological zones, pastoral resource areas and maintaining an equitable balance between use of land for pasture and agriculture. However, zoning of rangelands has not been implemented and the development interventions that are currently promoted in rangelands are inclined towards intensive crop and livestock development with none focused on pastoralism. The second National Development Plan prioritizes livestock production through implementing intensive measures such as improving access for water for livestock and veterinary services for sedentary livestock farmers (Government of Uganda 2015) but does not integrate provisions in the National Land Policy, 2013, to secure rangelands from being converted into other uses.

Developing commercial tree plantations to meet Uganda's energy demand is one of the investment opportunities stated in the Renewable Energy Policy, 2007, and Renewable Investment Guide of Uganda (Government of Uganda 2012). This has been embraced by mandated agencies through promotion of commercial tree planting for bioenergy production in rangeland areas, especially in north-eastern Uganda. Similarly, the Forestry
Policy, 2001, provides for the development of commercial forest plantations for bioenergy and timber (Government of Uganda 2001). This has been promoted through subsidies involving the renting of state-owned land at nominal rates by government agencies to private investors to plant exotic tree species that are of commercial value. In certain cases, grants such as the Saw Log Production Grant Scheme (funded by Government of Uganda and European Commission) have been availed to support establishment of forest plantations for timber production on highly productive rangelands.

\section{Fire exclusion}

Exclusion of fire was initiated by colonial agricultural officers and sustained by post-independence governments. Prior to the arrival of the British colonial administrators in Uganda, pastoralists used fire as a rangeland management strategy to remove unpalatable plants, rejuvenate forage material, and control encroachment of undesirable plants (Oba 2012, Oba et al. 2008). In 1900, forest protection regulations enacted under Article 99 of the African Orders in Council of 1889 were enacted and the regulations made it a punishable offence to cause or set fire to a crown forest which included woodlands in rangeland areas (Turyahabwe and Banana 2008).

Later after independence, a decree called "The Prohibition of the Burning of Grass Act" was passed in 1974 by President Idi Amin, and it is still in-force today. This law restricts the use of fire in the management of rangelands on private land except in wildlife conservation areas and forest reserves as a management tool, and the burning has to be done by an authorized officer of the agency. It allows for few exceptions, such as clearing land for development, farming and creating fire breaks to protect life and property. Exemptions must be sought from authorities in Agricultural and Veterinary Departments with supervision of a parish chief. The decision to allow burning is at the discretion of the Officer and Authority provided in the law. The layers of authority associated with granting permission to burn were intended to minimize the use of fire.

Negative attitudes towards the use of fire in rangeland management have persisted in Uganda and in other regions of Africa, because of the colonial bias of conserving forests and woodlands and the perceived fears that fires can cause increased soil erosion and subsequently loss of soil fertility and biodiversity loss (Laris and Wardell 2006, Rodgers et al. 2002). Fire is viewed as having deleterious effects on woody and grass species richness (Smart et al. 1985) and that it precipitates the decline of trees by inhibiting recruitment (Nangendo 2005). It is also argued that regular fires reduce production and nutritive value of grasses and that enhances growth of non-palatable grass species (Harrington 1974). 
Fire exclusion has been further promoted by national and international conservation civil society organizations that have advanced the notion that fire is harmful and leads to land degradation (Furley et al. 2008, Hoben 1996).

Increasing recognition that fire exclusion reduces carbon dioxide emissions by storing carbon in woody biomass and soils has further encouraged restrictions on burning in the current era of climate change (Houghton et al. 1999, Tilman et al. 2000) where practices that are perceived to reduce emissions are being promoted.

\section{Consequences of current land use policies and trends}

\section{Land individualization and pastoral sedentarization}

The interventions to promote individualization of land and sedentarization of pastoralists in Uganda were 'system blind' considering that they did not acknowledge the strength of pastoralism as a 'working model' that is intricately connected to the ecological functioning of the rangelands (Krätli 2010). This resulted in the displacement of pastoral communities (Kisamba-Mugerwa et al. 2006, Muhereza 2001). For example, in south-western Uganda, a total of 248,400 ha of pastoral land that was owned by Bahima pastoralists was allocated to 207 individual ranchers in the 1960 s, partly because most of the Bahima could not fulfil government criteria necessary for the selection of beneficiaries, including literacy and experience in business management (Pulkol 1994). This left thousands of pastoralists landless and many of them up to today are still moving into areas which were traditionally not part of their "territory" and this has been a source of conflicts with host communities (Mabikke 2011).

All the land in Karamoja (north-eastern Uganda) used to be communally owned at the time the British colonial administration was established in Uganda, but communal land currently occupies only $50 \%$ of the total land available to pastoralists due to increased individualization of land (Rugadya and Kamusiime 2013). In other parts of the country especially in central, western and southern Uganda, communal land that pastoralists can use opportunistically following their traditional practices of rearing livestock is becoming non-existent. Pastoralists have been pushed to small marginal parcels of land that have not been leased to private individual ranchers (Muhereza 2001).

Individualization of land has increased pastoralists' exposure to risks by depriving them of realizing benefits that are derived from landscape heterogeneity in consolidated landscapes, such as access to common grazing land, water and dry season resources (Kisamba-Mugerwa et al. 2006, Rugadya 1999).

Land individualization has exacerbated the problem of fragmentation of rangelands and significantly reduced livestock migration routes (Byenkya et al. 2014), which has been found elsewhere to increase livestock vulnerability to drought (Nkedianye et al. 2011). Flexible and opportunistic pastoral systems that are shaped by functional resource heterogeneity to cope with weather and forage variability cannot be implemented when rangelands are owned individually (Oba et al. 2008, Turner et al. 2016).

Studies on the socio-ecological impacts of sedentarization of pastoralists in Uganda are scarce; however, research in other neighbouring countries especially in the rangelands of Kenya have shown that sedentarization has led to low grass biomass and slower grass recovery after very dry periods (Groom and Western 2013). This is because livestock mobility is critical for maintaining residual biomass in long dry periods (Illius and O'connor 1999), yet this capacity is limited by sedentarization.

Sedentarization of pastoralists results in prolonged occupation of livestock within a given area and the subsequent impoverishment and local degradation of the landscape due to over use (Munyao and Barrett 2007, Weber and Horst 2011).This is known to contribute to low forage biomass productivity (Western et al. 2015) and species diversity (Ning and Richard 1999). Sedentarization creates social, economic and ecological changes, thus affecting the sustainability of social-ecological systems (Nkedianye et al. 2011, Schwartz 2005). Fratkin et al. (2004) found sedentarized pastoralists in the Marsabit area of Kenya's northern region to have the lowest income and regularly experience food insecurity. In a related study, Kamara et al. (2004) found that sedentarization led to increased land disputes because territorial boundaries are difficult to honour in a landscape where resources to support livelihoods vary at spatial and temporal scales.

The process of sedentarization of pastoralists has led to localized degradation owing to intense grazing pressure in the central plains of Karamoja (north-east Uganda) that is further exacerbated by the development of multiple piospheres around waterholes in the region (Egeru et al. 2015). Similarly, Mugerwa and Zziwa (2014) found that sedentarization of pastoralists in Karamoja had led to degradation of the few water points that pastoralists can access, mainly due to increased grazing intensity and duration.

Reduced mobility has led to degradation and decline in grassland cover in some parts of central Uganda where most of the rangelands were parceled out into individual ranches, thus jeopardizing livestock production and threatening livelihoods of rangeland communities (Mugerwa and Zziwa 2014). The common indicators of degradation linked to sedentarization of pastoralists in the rangelands of Uganda include silting of water sources (Zziwa et al. 2012), increased bare surfaces, and signs of soil erosion such as gullies and rills (Mugerwa and Zziwa 2014). 


\section{Rangeland conversion to alternative land uses}

Rangeland conversion to alternative land uses intensifies impacts on remaining rangelands, thus potentially creating deleterious impacts on rangeland condition and the diverse ecosystem services that rangelands supply (Hobbs et al. 2008). Conversion to cropland in which the perennial vegetative cover is removed and the soil disturbed can cause widespread degradation (Yang et al. 2005), biodiversity loss (Alkemade et al. 2013) and carbon loss (Chuluun and Ojima 2002). Collectively, these land-use changes make pastoral communities more vulnerable and less resilient to changes in the biophysical environment (living and non-living components of the environment) (Reid et al. 2014).

In their assessments of land-cover change in the rangelands of central Uganda, Zziwa et al. (2012) found that grassland conversion to other land use, especially crop, coniferous tree plantation and settlement, is greater than the rate of grassland expansion, and if not addressed, it may result in the elimination of grasslands in the near future. Similarly, Egeru et al. (2014) found that cropland is replacing rangelands in north-eastern Uganda and cropland increased tenfold between 1986 and 2013. In a related study in the same area, Nakalembe et al. (2017) found that cropland area had increased by $299 \%$ between 2000 and 2011 in Karamoja subregion especially in Moroto district. They estimated that cropland increased from 706 to 23,328 hectares which is approxiamtely a thirty three fold increase. The growing of bananas quadrupled in the rangelands of Ankole sub-region (south-western Uganda) between 1970 and 1990 due to formal and informal market incentives that promoted bananas as the most commercially viable farming practice in the region (Gold et al. 1999).

Between 1990 and 2005, grasslands declined at an annual rate of $4 \%$ in Uganda due to mainly agricultural expansion (NFA 2010) and this resulted in a decline of biomass carbon density stocks (Nakakaawa et al. 2011) and overall sustainability of grassland ecosystems (Zziwa et al. 2012). This may have important ecological, social and economic implications for the nation due to loss of diverse and often overlooked ecosystem services from grasslands as they are converted to other land uses (Nakakaawa et al. 2011, National Forestry Authority 2010). These unique ecosystem services include provision of forage, carbon sequestration and storage (O'Mara 2012, Scurlock and Hall 1998), methane storage (Minami and Kimura 1993) and biodiversity conservation (Sala and Paruelo 1997).

\section{Fire exclusion}

Fire exclusion has contributed to the transition of grasslands to scattered and closed Acacia woodlands and loss of grass species in northern Uganda (Smart et al. 1985). The grasses that declined due to fire exclusion include Sporobolus robustus Kunth, Sporobolus pyramidalis P. Beauv. Hyparrhenia filipendula (Krauss) Stapf, Hyparrhenia rufa Stapf, Paspalum auriculatum J.presl, Setaria spp., Brachiara brizantha (Hochst. ex A. Rich.) Stapf. and Digitaria adscendens (Kunth) Henrard. Studies elsewhere (Gordijn et al. 2012) show that fire exclusion accelerates the rate of woody plant expansion into rangelands, with decreases in palatable species and increases in unpalatable species, which has negative effects on livestock production, especially of grazers.

Generally, fire exclusion in fire-dependent ecosystems such as grasslands results in encroachment of shrubs and trees (Roques et al. 2001, Wigley et al. 2009). Shrub and tree encroachment can affect the ecosystem structure and functioning, thus potentially affecting the utilitarian value (intended use) of rangelands (Eldridge et al. 2011). Fire exclusion may lead to decreases in: forage quality, plant vigour, nutrient cycling and availability, and can lead to greater fire intensities and severities, and increased insect and disease epidemics in rangelands (Keane et al. 2002), which can adversely affect pastoralists' livelihoods.

\section{Proposed road map and recommendations to address policy deficiencies}

The policy deficiencies that have been highlighted in this paper can be addressed if Uganda carries out comprehensive policy, legal and administrative reforms on rangelands and pastoralists. This requires raising the status of rangelands and pastoralists on the national policy agenda for action. The following steps will need to be undertaken to raise momentum for the proposed reforms:

(i) A national dialogue in which various actors can freely engage and deliberate on issues that require policy, legal and administrative reforms on rangelands and pastoralists, will be an important first step in raising the issues onto the national policy agenda. The dialogue should prioritize effective engagement and inclusion of the traditional users of rangelands through community dialogues to ensure that they are part and parcel of the processes determining policy direction on rangelands.

(ii) The dialogue should not only generate consensus and unity of purpose but also identify "change champions" from state and non-state actors that can create alliances and utilize these alliances to initiate reforms on rangelands and pastoralists in Uganda.

(iii) Setting up of working groups at national and regional level to pursue reforms on rangelands and pastoralists will be critical in engaging government agencies and development partners in Uganda. 
(iv) A well-thought-through communication and advocacy strategy for the working groups to formally engage Uganda's parliament, relevant ministries, departments, agencies and development partners will need to be formulated.

(v) The Ministry of Agriculture, Animal Industry and Fisheries, and state and non-state actors (including pastoralists' coalitions) involved in the use and management of rangelands would be the most appropriate to steer the processes of making reforms.

(vi) It will be important to formulate a road map that will guide implementation of the reforms.

The specific recommendations to address policy deficiencies linked to rangeland policies and trends of Uganda are described henceforth.

\section{Land individualization and pastoral sedentarization}

Land tenure reform that enhances tenure security, especially of fixed, discrete, key resource sites such as dryseason water sources and forage reserves, is critical for rangeland users involved in livestock production (Clover and Eriksen 2009, Sayre et al. 2013). It is important to recognize the inherent spatial and temporal variation of rangeland resources in livestock development planning policies (Scoones 1995). Land tenure that provides seasonal or transient access to allow mobility of livestock in heterogeneous environments may be worth exploring to make critical grazing resources available at all times of the year (Mwangi 2009, Turner et al. 2016).This will require land reforms such as legal recognition and codification of traditional land values and practices, transhumance corridors and decentralization of rangeland management to local communities to allow flexible use of rangeland resources (Turner et al. 2016).The focus needs to be on securing use rights and setting up resource management institutions other than private property rights. This is because mobility is a critical adaptation strategy to cope with the spatial and temporal variability of arid and semi-arid landscapes of most rangelands in the tropics (Zhuang and Li 2016).

Consolidation of land provides an opportunity to restore broader scale connectivity and utilization of heterogeneity in rangelands (Lackett and Galvin 2008). Small fragmented holdings have less flexibility to adjust to biophysical changes and are therefore more exposed to greater risk compared to consolidated landscapes (Stokes et al. 2006). Consolidation of land will require government intervention in formalizing land markets and policy actions such as fiscal disincentives in the form of taxes that minimize speculation (Nguyen et al. 1996) and enforcement of social sanctions and provision of incentives that promote land consolidation (Hobbs et al. 2008, Lesorogol 2010). The process described in text
Box 1 may be useful to guide consolidation of land in the rangelands of Uganda. It will be important to have robust legal and institutional frameworks and safeguards to address corruption and other forms of bad governance if the country is to benefit from dividends of land consolidation in rangeland areas.

\section{Box 1 Proposed process of initiating land consolidation in rangelands of Uganda}

- The Ministry of Agriculture, Animal Industry and Fisheries together with the Ministry of Lands, Housing and Urban Development and other non-state and state actors that have interest in rangelands will need to formulate and popularize guidelines that will enable effective and efficient registration of communal lands in rangeland areas.

- Deliberate efforts such as legal services, surveying and mobilization to support pastoralists and other livestock farmers to establish areas of common land use will be required from state and non-state actors.

- District Local Governments should ensure that Area Land Committees and District Land Boards that are mandated to provide land administration services are operational at all levels to facilitate the process of registering areas of common land use and handling any emerging grievances as prescribed in the Land Act, 1998.

- Ranch owners and other livestock farmers on privately owned land should be sensitized and incentivized by the Ministry of Agriculture, Animal Industry and Fisheries, Ministry of Lands, Housing and Urban Development and any other relevant state and non-state agencies to form cooperatives with a purpose of consolidating their land to enable flexible and adaptive use.

- The Ministry of Lands, Housing and Urban Development and other non-state and state actors that have interest in rangelands will need to work jointly in formulating grievance redress mechanisms that are effective, accessible and affordable to mitigate or prevent conflicts among users of areas of common land use in rangelands.

Livestock mobility needs to be perceived as an action that is legitimate and will benefit rangeland ecology, livestock productivity and pastoral risk management. Its adoption should be based on a comprehensive understanding of how patterns of livestock movement affect the spatio-temporal pressures on rangeland resources (Turner 2011). The starting point should be mapping of transhumance corridors to determine ways through which mobility can increase herds' access to forage and water between and within years (Turner et al. 2016). 
Local rangeland resource user groups such as pastoralists and ranchers, extension officers and responsible agencies of rangeland ecological resources such as Uganda Wildlife Authority, Wetlands Department, National Forestry Authority and local governments at the district and sub-county level should participate in monitoring how livestock movements affect the rangeland resources under their jurisdiction, following the policy and legal frameworks that prescribe their mandates. Pastoralists ought to be supported by the responsible agency (Ministry of Agriculture, Animal Industry and Fisheries) in developing site-specific guidelines for herd movement to ensure socio-ecological balance. The guidelines formulated should characterize drought reserves, transhumance corridors and water points and include socio-ecologically appropriate principles for their management.

\section{Rangeland conversion to alternative uses}

Policy actions that discourage the conversion of rangeland to other land uses need to be formulated to maintain the diverse and unique economic and ecological services that rangelands provide (Greene and Stager 2001, Sayre et al. 2013). This will require significant improvement in the communication and collaboration with the disciplines and sectors of society currently responsible for managing various land uses, in order to appreciate the composite value of ecosystem services provided by rangelands (Herrick et al. 2012). The starting point should be to determine the ecosystem service value of rangelands and its inclusion in the national accounting system. The services may include air purification, disturbance regulation, water regulation, water supply, erosion control and sediment retention, soil formation, waste water treatment, pollination, biological control of diseases, refugia, food production, raw materials, recreation and culture (Xie et al. 2000).

Policy actions that provide payments for conservation stewardship of rangelands should be explored and considered to encourage land owners to maintain their land as rangelands (Dougill et al. 2012, Dutilly-Diane et al. 2007) especially in Karamoja region (northeast Uganda) and central Uganda where rangeland conversion is highest (Egeru et al. 2014, Nakalembe et al. 2017, National Forestry Authority 2010, Zziwa et al. 2012).

Payment schemes similar to the environmental quality incentive program (EQIP) of the USA where incentives are provided for implementing conservation practices (Briske et al. 2017) can be explored to promote conservation of rangelands. Similar agri-environment schemes have been applied in Europe and realized positive results in terms of conservation of natural ecosystems and influencing farmers' behaviour to implement conservation practices (Burton and Schwarz 2013, Donald and Evans 2006, Klimek et al. 2008). It will be important to institute monitoring mechanisms that are consistent with the time required to achieve desired conservation outcomes on rangelands, to determine the performance of land owners in the sustainable management and use of rangelands (Briske et al. 2017).

\section{Fire exclusion}

Fire is an important tool used in management of rangelands, specifically to reduce bush encroachment, modify species composition of plant communities, maintain habitat for animals and ecological processes and sustain the distinctive nature of rangelands (Mapiye et al. 2008, Okello et al. 2008, Roques et al. 2001). Fire is essential in sustaining grassland ecosystems (Brockway et al. 2002) and increasing plant productivity in savanna rangelands through reducing above ground herbaceous biomass (Belsky et al. 1989) and releasing nutrients that were previously immobilized in organic matter (DeBano et al. 1998). Fire improves the palatability and nutritive value of existing forage in rangelands and improves forage production (Sabiiti et al. 1992). In their studies in South Africa, Bond and Archibald (2003) showed that fire is important in preventing woody plant expansion in grasslands and exclusion of fire will result into a vegetation shift from grasslands to forests. More so, Guevara et al. (1999) found the exclusion of fire in the rangelands of south-western Mendoza plains of Argentina resulted in dominance by unpalatable shrubs and grasses.

A mix of fire policies such as "natural" fire regime (mimicking lightening fires) for the maintenance of wilderness, patch mosaic burning to promote heterogeneity and burning to create habitat conditions required by certain groups of biota (Bond and Archibald 2003) need to be explored in Uganda. The starting point should be rigorous assessment of ecological and social impacts of fire in the different regions of Uganda.

This assessment is necessary to investigate fire management strategies that can best provision rangeland ecosystem services and the livelihoods dependent on them.

This can be followed by education, engagements and demonstrations with rangeland users to implement prescribed burning based on the fire ecology assessments conducted in their respective regions. This will require formation of fire management associations among rangeland users in various parts of the country, so as to implement the agreed and research-based fire management regimes. This will only be possible if the "The Prohibition of the Burning of Grass Act" (1974) is amended to allow the use of fire as a management tool in rangelands on privately owned land. 


\section{Proposed road map to address policy deficiencies}

It will be important to establish a National Commission for Rangelands in order to effectively implement the proposed recommendations. This is because of the multi-sectoral nature of the uses and benefits of rangelands. The Commission will be responsible for coordinating efforts of various state and non-state actors involved in rangeland use, so as to ensure policy coordination at various scales of operation. A Commission will have legal authority to demand accountability from other state agencies and non-state actors on their roles and activities in the management of rangelands as prescribed in the policy and laws governing rangeland use. The Commission will also provide technical advice in matters related to any land use activities that may jeopardize rangeland socio-ecological integrity.

Successful management of environmental resources involving different actors requires acknowledgement that there are multiple interests and multiple government agencies at play which may vary at spatial and temporal scale. Government agencies are not monolithic; each of them has their own mandates, and similarly local users of rangelands may have different interests and value systems (Berkes 2002). The draft rangeland management and pastoralism policy of Uganda recognizes that rangelands provide grazing pastures, wetlands, forests, arable land and water bodies that support pastoralists' and agro-pastoralists' livelihoods and other users who harness benefits from wildlife, woodlands, medicinal plants, minerals, scenic landscapes, watersheds and oil and gas.

The valuing of rangelands as expected is bound to be different among the different types of users that the policy identifies. In his paper, Berkes (2002) recommended that strong and effective cross-scale linkages among state and non-state actors is critical in building consensus when interests and values of environmental resources vary among actors.

In the case of Uganda, the actors such as Ministry of Agriculture, Animal Industry and Fisheries, Ministry of Water and Environment, Ministry of Lands, Housing and Urban Development, Ministry of Tourism and Antiquities, Ministry of Finance, Economic Planning and Development, Ministry of Local Government, Ministry of Energy and Mineral Development will all be critical in ensuring functional cross-scale linkages. Non-state actors who are critical will include but are not limited to: ranchers, pastoralists' coalitions, mining companies, Uganda chamber of mines and petroleum, and commercial agriculture companies operating in rangeland areas. Civil society organizations, academia, researchers and traditional or cultural leaders will also be important in harnessing cross-scale linkages.

The second National Development Plan of Uganda recognizes agriculture, tourism, minerals, oil and gas development and infrastructure development as priority areas for Uganda's quest for socio-economic transformation. The responsible and mandated ministries, departments and agencies ought to have functional coordination frameworks to harness existing synergies and minimize jeopardizing interests of other users of rangelands.

Cross-scale linkages enable combining the strengths of government agencies, non-state actors and local resource users and can be useful in mitigating the weaknesses identified by Pomeroy and Berkes (1997)). The linkages ought to be based on a robust policy, legal and institutional framework that that minimize dominance by powerful actors. This means ensuring that all actors espouse mutual respect, trust, and that decisions are made through consensus. Appropriate governance structures for sharing rights and responsibilities will address power dynamics (Adger et al. 2005).

Access to knowledge and information, fair distribution of benefits and costs, effective feedback mechanisms and participation in decision-making will be useful in ensuring power balance among actors (Cash et al. 2006, Robertson and Choi 2010). This will require policy and legal reforms that provide for well-defined separation of power and roles, obligations, responsibilities and accountability mechanisms of state and non-state actors involved rangeland use and management.

The Ministry of Lands and Housing and Urban Development should ensure that rangelands are provided with land-use plans to regulate their conversion into other uses. The National Planning Authority should ensure that all agencies that have certain roles in the management of rangelands have integrated these roles in their plans and are implementing them as provided. The Ministry of Local Government should ensure that priorities and strategies provided in the policy governing rangelands are translated in the district development plans, budgets and workplans.

The National Environment Management Authority should carry out regular monitoring and reporting on the quality of natural ecosystems in rangelands of Uganda as required by the Environment Act, 1995, and ensure that development projects do not cause adverse impacts on rangelands. The Ministry of Finance, Planning and Economic Development should ensure that the technical and financial performance contracts with government agencies reflect sustainable rangeland management priorities.

\section{Conclusions}

This assessment of historical and contemporary land use and economic policies and their consequences has shown that a continuation and, in several cases, an acceleration of policies originating from the colonial era 
have had a series of adverse impacts on rangeland resources and pastoralists in Uganda. These policies focused on the production efficiency of a small number of provisioning ecosystem services that was characteristic of natural resource use at that time without any consideration of other regulatory, cultural and supporting ecosystem services from rangelands. These policies continued even after independence because of the powerful, widely perceived images of environmental change such as land degradation and desertification that were linked to traditional practices of rangeland use inherited by post-independence governments in Africa (Leach and Mearns 1996).

These images have been further perpetuated by multi-lateral donor agencies which contribute to the entrenchment of specific "environmental narratives" (Hoben 1996) through budgetary support of government agencies responsible for managing environmental resources, including rangelands (Leach and Mearns 1996).

Policies that promote individualization of land and sedentarization have limited livestock mobility and flexibility in use of rangeland resources, led to break down of social networks that provide safety nets, and thus caused decline in rangeland productivity, increased livestock mortality during drought and negatively affected the livelihoods of pastoralists. While fire exclusion has led to increased bush encroachment, an increase in unpalatable grass species and rangeland conversion into other land uses has led to fragmentation of rangelands, which is causing decline in available forage and habitats for grazers.

The policy issues and objectives have been characterized more by political interests rather than objectivity by the relevant state ministries and non-state actors. This conclusion is premised on the fact that despite the adverse impacts of the policies analysed, they continue to remain dominant in Uganda's policy arena. In Uganda, recent knowledge showing the need to rethink rangelands policies which only focus on production efficiency of a few provisioning ecosystem services of rangelands has not been mainstreamed in land use and economic policies. Other regulatory, cultural and supporting ecosystem services from rangelands also have not been prioritized in these policies.

Rangelands ought to be valued for the full suite of economic and ecological services they provide, rather than as a residual category which promotes their continued loss to more intensive uses (Sayre et al. 2013). This can be achieved if Uganda's policies enhance the socio-ecological balance of rangelands. This will require regular policy evaluation, incorporation of insights into practice and working towards a shared purpose in rangeland use (Homewood 2004).

Establishment of a National Rangeland Commission governed by an executive Board whose membership is strategically constituted for effective representation of relevant actors in the use of rangelands may be a good starting point to address the pitfalls of having scattered provisions under different agencies with diverse mandates and interests. It will be useful to formulate a policy and enact a law and regulations providing a mandate to the proposed Commission, to ensure sustainable management and use of rangelands. It will be pertinent that Ugandan rangelands are recognized as natural ecosystems that require legislation for the continuation of their ecosystem services for posterity.

\section{Endnote}

${ }^{1}$ Uganda Protectorate, 1961, Report of the Karamoja Security Committee, p.vii.

\section{Acknowledgements}

The authors wish to acknowledge Texas A\&M University and USAID who supported the first author during his time as a "visiting professor" at the Department of Ecosystem Science and Management, Texas A\&M University, College Station, USA, where the idea of writing this review paper was initiated together with the last author. Kenneth Balikoowa of the Department of Environmental Management, Makerere University, is acknowledged for reviewing the initial drafts of this paper.

\section{Funding \\ There is no funding body to declare.}

\section{Authors' contributions}

PB analysed the relevant policies in terms of their socio-ecological and economic consequences on rangelands and pastoralists. He also drafted the introduction section of the manuscript and suggested the recommendations to address the consequences. He collated all the sections from the other co-authors. AE reviewed and analysed the historical policy trends that have shaped land governance in the rangelands of Uganda. He also reviewed ecological consequences of some of the policies that have shaped rangeland management in Uganda. BB reviewed ecological consequences of some of the policies especially on land-use/land-cover changes. He validated some of the data on land-use/land-cover changes associated to certain policies that were reviewed. DDB formulated the research questions that guided the review, reviewed some of the socio-ecological consequences of some of the dominant policies in rangeland management and proposed some of the recommendations to address identified consequences. All authors read and approved the final manuscript.

\section{Competing interests}

The authors declare that they have no competing interests.

\section{Publisher's Note}

Springer Nature remains neutral with regard to jurisdictional claims in published maps and institutional affiliations.

\section{Author details \\ ${ }^{1}$ Department of Environmental Management, Makerere University, P.O Box 7062, Kampala, Uganda. ${ }^{2}$ Regional Universities Forum for Capacity Building in Agriculture (RUFORUM), P.O. Box 16811, Wandegeya, Kampala, Uganda. ${ }^{3}$ Department of Ecosystem Science and Management, Texas A\&M University, College Station, TX 77843, USA.}

Received: 6 October 2017 Accepted: 13 December 2017

Published online: 05 March 2018

\section{References}

Adger, W. Neil, Katrina Brown, and Emma Tompkins. 2005. The political economy of cross-scale networks in resource co-management. Ecology and Society 10 (2). www.ecologyandsociety.org/vol10/iss2/art9/. 
Alkemade, Rob, Robin S. Reid, Maurits van den Berg, Jan de Leeuw, and Michel Jeuken. 2013. Assessing the impacts of livestock production on biodiversity in rangeland ecosystems. Proceedings of the National Academy of Sciences 110 (52): 20900-20905.

Barber, James P. 1962. The Karamoja District of Uganda. The Journal of African History 3 (1): 111-124.

Barrows, Richard, and Michael Roth. 1990. Land tenure and investment in African agriculture: Theory and evidence. The Journal of Modern African Studies 28 (2): 265-297.

Bataringaya, B. 1961. K, report of the Karimojong Security Committee. Entebbe: Government Printer.

Belsky, A.J., R.G. Amundson, J.M. Duxbury, S.J. Riha, A.R. Ali, and S.M. Mwonga. 1989 The effects of trees on their physical, chemical and biological environments in a semi-arid savanna in Kenya. Journal of Applied Ecology 26: 1005-1024.

Berkes, Fikret. 2002. Cross-scale institutional linkages for commonsmanagement: perspectives from the bottom up. In The Drama of the Commons. ed. Elinor Ostrom, Thomas Dietz, Nives Dolsak, Paul C. Stern, Susan Stonich. 293-321. Washington, D.C: National Academy EU Weber.

Beyaraza, Ernest. 2004. Evolution of property rights in Uganda: A legal and philosophical analysis of past, present, and future trends. Makerere University Printery.

Bond, William J., and Sally Archibald. 2003. Confronting complexity: Fire policy choices in South African savanna parks. International Journal of Wildland Fire 12 (4): 381-389.

Briske, David D., Brandon T. Bestelmeyer, Joel R. Brown, Mark W. Brunson, Thomas L. Thurow, and J.A. Tanaka. 2017. Assessment of USDA-NRCS rangeland conservation programs: Recommendation for an evidence-based conservation platform. Ecological Applications 27 (1): 94-104.

Brock, Beverley. 1969. Customary land tenure, 'individualization' and agricultural development in Uganda. East African Journal of Rural Development 2 (2): 1-27.

Brockway, Dale G., Richard G. Gatewood, and Randi B. Paris. 2002. Restoring fire as an ecological process in shortgrass prairie ecosystems: Initial effects of prescribed burning during the dormant and growing seasons. Journal of Environmental Management 65 (2): 135-152.

Burton, Rob J.F., and Gerald Schwarz. 2013. Result-oriented agri-environmental schemes in Europe and their potential for promoting behavioural change. Land Use Policy 30 (1): 628-641.

Byenkya, G.S., S. Mugerwa, S. Barasa, and E. Zziwa. 2014. Land use and cover change in pastoral systems of Uganda: Implications on livestock management under drought induced pasture. African Crop Science Journal 22: 1013-1025.

Cash, David, W. Neil Adger, Fikret Berkes, Po Garden, Louis Lebel, Per Olsson, Lowell Pritchard, and Oran Young. 2006. Scale and cross-scale dynamics: Governance and information in a multilevel world. Ecology and Society 11 (2). www.ecologyandsociety.org/vol11/iss2/art8/.

Chapman, Chris, and Alexander Kagaha. 2009. Resolving conflicts using traditional mechanisms in the Karamoja and Teso regions of Uganda. Minority Rights Group briefing.

Chuluun, Togtohyn, and Dennis Ojima. 2002. Land use change and carbon cycle in arid and semi-arid lands of East and Central Asia. Science in China Series C Life Sciences-English Edition 45 (SUPP): 48-54.

Clover, J., and S. Eriksen. 2009. The effects of land tenure change on sustainability: Human security and environmental change in southern African savannas. Environmental Science \& Policy 12 (1): 53-70.

DeBano, Leonard F., Daniel G. Neary, and Peter F. Ffolliott. 1998. Fire effects on ecosystems. Wiley

Donald, Paul F., and Andy D. Evans. 2006. Habitat connectivity and matrix restoration: The wider implications of agri-environment schemes. Journal of Applied Ecology 43 (2): 209-218.

Doornbos, Martin R. 1975. Land tenure and political conflict in Ankole, Uganda. The Journal of Development Studies 12 (1): 54-74.

Doornbos, Martin R., and Michael F. Lofchie. 1970. Ranching and scheming: A case study of the Ankole ranching scheme. Institute of social studies.

Dougill, Andrew J., Lindsay C. Stringer, Julia Leventon, Mike Riddell, Henri Rueff, Dominick V. Spracklen, and Edward Butt. 2012. Lessons from communitybased payment for ecosystem service schemes: From forests to rangelands. Philosophical Transactions of the Royal Society of London B: Biological Sciences 367 (1606): 3178-3190.

Dutilly-Diane, Céline, Nancy McCarthy, Francis Turkelboom, Adriana Bruggeman, James Tiedemann, Kenneth Street, and Gianluca Serra. 2007. Could payments for environmental services improve rangeland management in Central Asia, West Asia and North Africa?

Egeru, Anthony, Oliver Wasonga, Kyagulanyi Joseph, G.J. Mwanjalolo Majaliwa, Laban MacOpiyo, and John Mburu. 2014. Spatio-temporal dynamics of forage and land cover changes in Karamoja sub-region, Uganda. Pastoralism 4 (1): 6.

Egeru, Anthony, Oliver Wasonga, Laban MacOpiyo, John Mburu, John R.S. Tabuti, and Mwanjalolo G.J. Majaliwa. 2015. Piospheric influence on forage species composition and abundance in semi-arid Karamoja sub-region, Uganda. Pastoralism 5 (1): 12.

Eldridge, David J., Matthew A. Bowker, Fernando T. Maestre, Erin Roger, James F. Reynolds, and Walter G. Whitford. 2011. Impacts of shrub encroachment on ecosystem structure and functioning: Towards a global synthesis. Ecology Letters 14 (7): 709-722.

Emerton, Lucy. 1999. Balancing the opportunity costs of wildlife conservation for communities around Lake Mburo National Park, Uganda. IIED.

Filipová, Zuzana, and Nadia Johanisova. 2017. Changes in pastoralist commons management and their implications in Karamoja (Uganda). Journal of Political Ecology 24 (1): 881-900.

Fratkin, Elliot, Eric Abella Roth, and Martha A. Nathan. 2004. Pastoral sedentarization and its effects on children's diet, health, and growth among Rendille of Northern Kenya. Human Ecology 32 (5): 531-559.

Furley, Peter A., Robert M. Rees, Casey M. Ryan, and Gustavo Saiz. 2008. Savanna burning and the assessment of long-term fire experiments with particular reference to Zimbabwe. Progress in Physical Geography 32 (6): 611-634.

Gold, C.S., E.B. Karamura, A. Kiggundu, F. Bagamba, and A.M.K. Abera. 1999. Geographic shifts in the highland cooking banana (Musa spp., group AAAEA) production in Uganda. International Journal of Sustainable Development and World Ecology 6 (1): 45-59.

Gordijn, Paul J., Edward Rice, and David Ward. 2012. The effects of fire on woody plant encroachment are exacerbated by succession of trees of decreased palatability. Perspectives in Plant Ecology, Evolution and Systematics 14 (6): 411-422.

Government of Uganda, ed. 2001. The Uganda Forestry Policy 2001 edited by Government of Uganda. Kampala: Government of Uganda.

Government of Uganda. 2008. The national livestock census report 2008. Entebbe: Ministry of Agriculture, Animal Industry \& Fisheries.

Government of Uganda. 2010. The first National Development Plan. Kampala: National Planning Authority.

Government of Uganda. 2012. Renewable energy investment quide. Kampala: Ministry of Energy and Mineral Development.

Government of Uganda. 2014. Draft rangeland management and pastoralism policy. Kampala: Animal Industry and Fisheries Ministry of Agriculture.

Government of Uganda. 2015. The second National Development Plan. Kampala: National Planning Authority.

Government of Uganda. 2016. Draft biomass report. Kampala: National Forestry Authority.

Green, Elliott D. 2006. Ethnicity and the politics of land tenure reform in central Uganda. Commonwealth \& Comparative Politics 44 (3): 370-388.

Greene, Richard P., and John Stager. 2001. Rangeland to cropland conversions as replacement land for prime farmland lost to urban development. The Social science Journal 38 (4): 543-555.

Groom, Rosemary J., and David Western. 2013. Impact of land subdivision and sedentarization on wildlife in Kenya's southern rangelands. Rangeland Ecology \& Management 66 (1): 1-9.

Guevara, J.C., C.R. Stasi, C.F. Wuilloud, and O.R. Estevez. 1999. Effects of fire on rangeland vegetation in south-western Mendoza plains (Argentina): Composition, frequency, biomass, productivity and carrying capacity. Journal of Arid Environments 41 (1): 27-35.

Harrington, G.N. 1974. Fire effects on a Ugandan savanna grassland. Tropical grasslands.

Herrick, J.E., J.R. Brown, B.T. Bestelmeyer, S.S. Andrews, Baldi German, J. Davies, M. Duniway, K.M. Havstad, J.W. Karl, and D.L. Karlen. 2012. Revolutionary land use change in the 21 st century: Is (rangeland) science relevant? Rangeland Ecology \& Management 65 (6): 590-598.

Hobbs, N. Thompson, Kathleen A. Galvin, Chris J. Stokes, Jill M. Lackett, Andrew J. Ash, Randall B. Boone, Robin S. Reid, and Philip K. Thornton. 2008. Fragmentation of rangelands: Implications for humans, animals, and landscapes. Global Environmental Change 18 (4): 776-785.

Hoben, Allan. 1996. The cultural construction of environmental policy: Paradigms and politics in Ethiopia.

Homewood, Katherine M. 2004. Policy, environment and development in African rangelands. Environmental Science \& Policy 7 (3): 125-143.

Hoornbeek, John A., and B. Guy Peters. 2017. Understanding policy problems: A refinement of past work. Policy and Society 36 (3): 365-384. 
Houghton, R.A., J.L. Hackler, and K.T. Lawrence. 1999. The US carbon budget: Contributions from land-use change. Science 285 (5427): 574-578.

Illius, A.W., and T.G. O'connor. 1999. On the relevance of nonequilibrium concepts to arid and semiarid grazing systems. Ecological Applications 9 (3): 798-813.

Joughin, James, and Anne Mette Kjær. 2010. The politics of agricultural policy reform: The case of Uganda. In Forum for development studies.

Kalabamu, Faustin T. 2000. Land tenure and management reforms in East and Southern Africa - the case of Botswana. Land Use Policy 17 (4): 305-319.

Kamara, Abdul B., Brent Swallow, and Michael Kirk. 2004. Policies, interventions and institutional change in pastoral resource management in Borana, Southern Ethiopia. Development Policy Review 22 (4): 381-403.

Keane, Robert E., Kevin C. Ryan, Thomas T. Veblen, Craig D. Allen, Jesse A. Logan, Brad Hawkes, and J. Barron. 2002. The cascading effects of fire exclusion in Rocky Mountain ecosystems. In "rocky mountain futures" An Ecological Perspective. ed. Jill S. Baron. 133-152. Washington, DC: Island press.

Kirkbride, Mary, and Richard Grahn. 2008. Survival of the fittest: Pastoralism and climate change in East Africa. Oxfam Policy and Practice: Agriculture, Food and Land 8 (3): 174-220

Kisamba-Mugerwa, W. 1992. Rangeland tenure and resource management: An overview of pastoralism in Uganda. Makerere Institute of Social Research.

Kisamba-Mugerwa, Wilberforce. 1995. The impact of individualisation on common grazing land resources in Uganda. PhD, Makerere Institute of Social Research, Makerere University.

Kisamba-Mugerwa, Wilberfroce, John Pender, and E. Kato. 2006. Impacts of individualization of land tenure on livestock and rangeland management in Southwestern Uganda. In 11th Biennial Conference of the International Association for the Study of Common Property, IFPR Institute, Editor.

Klimek, Sebastian, Horst-Henning Steinmann, Jan Freese, and Johannes Isselstein. 2008. Rewarding farmers for delivering vascular plant diversity in managed grasslands: A transdisciplinary case-study approach. Biological Conservation 141 (11): 2888-2897.

Knighton, Ben. 2006. Can notions of common property and the common good survive? The consequences of classical economics for Karamojong nomadic pastoralists. IASCP Conference.

Krätli, Saverio. 2010. Karamoja with the rest of 'the rest of Uganda'. Nomadic Peoples 14 (2): 3-23.

Kyagaba, Emmanuel. 2004. Range resource assessment and monitoring techniques among the pastoral Bahima in Uganda. Nomadic Peoples 8 (1): 81-97.

Lackett, Jill, and Kathleen Galvin. 2008. From fragmentation to reaggregation of rangelands in the northern great plains: USA. In Fragmentation in Semi-Arid and Arid Landscapes: consequences for human and natural systems. eds. KA Galvin, RS Reid, RH Behnke, NT Hobbs. 113-134. Dordrecht: Springer

Laris, Paul, and David Andrew Wardell. 2006. Good, bad or 'necessary evil'? Reinterpreting the colonial burning experiments in the savanna landscapes of West Africa. The Geographical Journal 172 (4): 271-290.

Lastarria-Cornhiel, S. 2003. Uganda country brief: Property rights and land markets: USAID.

Leach, Melissa, and Robin Mearns. 1996. Environmental change and policy. In The lie of the land: Challenging received wisdom on the African environment, 1-33. Oxford: James Currey.

Lesorogol, Carolyn K. 2010. Creating common grazing rights on private parcels: How new rules produce incentives for cooperative land management. In: cooperation in economy and society. ed. R Marshall. Lanham, MD. 239-258. Alta Mira press.

Ministry of Agriculture Animal Industry and Fisheries Uganda, Uganda Bureau of Statistics, Food and Agriculture Organization of the United Nations, International Livestock Research Institute, World Resources Institute. 2010 Mapping a better future: Spatial analysis and pro-poor livestock strategies in Uganda. Washington, DC and Kampala: World Resources Institute.

Mabikke, Samuel B. 2011. Escalating land grabbing in post-conflict regions of Northern Uganda: A need for strengthening good land governance in Acholi region. International conference on global land grabbing.

Mamdani, Mahmood. 1982. Karamoja: Colonial roots of famine in North-East Uganda. Review of African Political Economy 9 (25): 66-73.

Mapiye, C., M. Mwale, N. Chikumba, and M. Chimonyo. 2008. Fire as a rangeland management tool in the savannas of southern Africa: A review. Tropical and Subtropical Agroecosystems 8 (2): 115-124.

Minami, K., and T. Kimura. 1993. The significance of grasslands in absorption of atmospheric methane and emission of nitrous oxide. Journal of Agricultural Meteorology 48 (5): 719-722.
Msuya, D.G. 2015. Pastoralism beyond ranching: A farming system in severe stress in semi-arid tropics especially in Africa. Journal of Agriculture and Ecology Research International 4 (3): 128-139.

Mugasi, S.K., E.N. Sabiiti, and B.M. Tayebwa. 2000. The economic implications of bush encroachment on livestock farming in rangelands of Uganda. African Journal of Range and Forage Science 17 (1-3): 64-69.

Mugerwa, Swidiq, and Emmanuel Zziwa. 2014. Drivers of grassland ecosystems' deterioration in Uganda. Applied Science Reports 2 (3): 103-111.

Muhereza, Frank Emmanuel. 2001. Ranchers and pastoralists: Restructuring of government ranching, Uganda, 100-133. London: African Pastoralism: Conflict, Institutions and Government, Pluto Press.

Munyao, Kioko, and Christopher B. Barrett. 2007. Decentralization of pastoral resources management and its effects on environmental degradation and poverty: Experience from northern Kenya. In Decentralization and the social economics of development: Lessons from Kenya, ed. C.B. Barrett, A.G. Mude, and J.M. Omiti, 97-110. United Kingdom: CAB International.

Mwangi, Esther. 2009. Property rights and governance of Africa's rangelands: A policy overview. Natural Resources Forum.

Mwaura, Francis, and Miriam Katunze. 2014. Enhancing agricultural production and productivity in Uganda through irrigation. Economic Policy Research Centre (EPRC).

Nakakaawa, Charlotte Anne, Paul O. Vedeld, and Jens B. Aune. 2011. Spatial and temporal land use and carbon stock changes in Uganda: Implications for a future REDD strategy. Mitigation and Adaptation Strategies for Global Change 16 (1): $25-62$.

Nakalembe, Catherine, Jan Dempewolf, and Christopher Justice. 2017. Agricultural land use change in Karamoja region, Uganda. Land Use Policy 62: 2-12.

Nangendo, Grace. 2005. Changing forest-woodland-savanna mosaics in Uganda: With implications for conservation.

National Forestry Authority. 2010. National biomass study technical report 2009. Kampala: National Forestry Authority.

Nguyen, Tin, Enjiang Cheng, and Christopher Findlay. 1996. Land fragmentation and farm productivity in China in the 1990s. China Economic Review 7 (2): 169-180.

Ning, Wu, and C.E. Richard. 1999. The privatisation process of rangeland and its impacts on the pastoral dynamics in the Hindu Kush Himalaya: The case of Western Sichuan, China. In People and rangelands. Townsville: Proceedings of VI International Rangelands Congress.

Nkedianye, David, Jan de Leeuw, Joseph O. Ogutu, Mohammed Y. Said, Terra L. Saidimu, Shem C. Kifugo, Dickson S. Kaelo, and Robin S. Reid. 2011. Mobility and livestock mortality in communally used pastoral areas: The impact of the 2005-2006 drought on livestock mortality in Maasailand. Pastoralism: Research, Policy and Practice 1 (1): 17.

Nsamba, Morris Adam. 2013. Decentralization and territorial politics: The dilemma of constructing and managing identities in Uganda. Critical African Studies 5 (1): 48-60.

Oba, Gufu. 2012. Harnessing pastoralists' indigenous knowledge for rangeland management: Three African case studies. Pastoralism: Research, Policy and Practice 2 (1): 1.

Oba, Gufu, Patrick Byakagaba, and Ayana Angassa. 2008. Participatory monitoring of biodiversity in East African grazing lands. Land Degradation \& Development 19 (6): 636-648.

Ocan, Charles Emunyu, and Charles Ocan. 1994. Pastoral resources and conflicts in north-eastern Uganda: The Karimojong case. Nomadic Peoples 34 (35): 123-135.

Okello, B.D., Truman P. Young, Corinna Riginos, Dan Kelly, and T.G. O'connor. 2008. Short-term survival and long-term mortality of Acacia drepanolobium after a controlled burn. African Journal of Ecology 46 (3): 395-401.

Okuku, Juma Anthony. 2006. The land act (1998) and land tenure reform in Uganda. Africa Development 31 (1): 1-26.

O'Mara, Frank P. 2012. The role of grasslands in food security and climate change. Annals of Botany 110 (6): 1263-1270.

Otim, P. 2004. Baseline study for the Ugandan side of the Karamoja cluster. Addis Ababa: Centre for Basic Research.

Pearson, Amber L., and Charles Muchunguzi. 2011. Contextualizing privatization and conservation in the history of resource management in southwestern Uganda: Ethnicity, political privilege, and resource access over time. The International Journal of African Historical Studies 44 (1): 113-140.

Platteau, Jean-Philippe. 1996. The evolutionary theory of land rights as applied to sub-Saharan Africa: A critical assessment. Development and Change 27 (1): $29-86$

Pomeroy, Robert S., and Fikret Berkes. 1997. Two to tango: The role of government in fisheries co-management. Marine Policy 21 (5): 465-480. 
Pulkol, David. 1994. Resettlement and integration of pastoralists in the national economy: Ranch restructuring in Uganda. In Conference on environment and settlement issues in Africa.

Quam, Michael D. 1978. Cattle marketing and pastoral conservatism: Karamoja District, Uganda, 1948-1970. African Studies Review 21 (1): 49-71.

Reid, Robin S., María E. Fernández-Giménez, and Kathleen A. Galvin. 2014. Dynamics and resilience of rangelands and pastoral peoples around the globe. Annual Review of Environment and Resources 39: 217-242.

Robertson, Peter J., and Taehyon Choi. 2010. Ecological governance: Organizing principles for an emerging era. Public Administration Review 70 (s1): 89-99

Rodgers, W.A., R. Nabanyumya, E. Mupada, and L. Persha. 2002. Community conservation of closed forest biodiversity in East Africa: Can it work? UNASYLVA-FAO 209(53): 41-53.

Roques, K.G., T.G. O'connor, and A.R. Watkinson. 2001. Dynamics of shrub encroachment in an African savanna: Relative influences of fire, herbivory, rainfall and density dependence. Journal of Applied Ecology 38 (2): 268-280

Roschinsky, R., H. Mulindwa, E. Galukande, M. Wurzinger, D. Mpairwe, A.M. Okeyo, and J. Sölkner. 2012. Pasture use and management strategies in the Ankole pastoral system in Uganda. Grass and Forage Science 67 (2): 199-209.

Rugadya, Margaret. 1999. Land reform: The Ugandan experience. Kigali: Land use and Villagisation Workshop.

Rugadya, Margaret A., and Herbert Kamusiime. 2013. Tenure in mystery: The status of land under wildlife, forestry and mining concessions in Karamoja region, Uganda. Nomadic Peoples 17 (1): 33-65.

Sabiiti, Elly N., John B. Wamara, Asaph A. Ogen-Odoi, and Ross W. Wein. 1992. The role of fire in pasture and rangeland management. Nomadic Peoples 31: 107-110

Sala, Osvaldo E., and José M. Paruelo. 1997. Ecosystem services in grasslands. In Nature's Services: Societal dependence on natural ecosystems. Ed. GC. 237-252. Washington, DC: Daily Island press.

Sayre, Nathan F., Ryan R.J. McAllister, Brandon T. Bestelmeyer, Mark Moritz, and Matthew D. Turner. 2013. Earth stewardship of rangelands: Coping with ecological, economic, and political marginality. Frontiers in Ecology and the Environment 11 (7): 348-354

Schwartz, H. JÜRgen. 2005. Ecological and economic consequences of reduced mobility in pastoral livestock production systems. In: Fratkin, E and Roth, E A (Eds.) As Pastoralists Settle 1: 69-86. New York: Springer.

Scoones, lan. 1995. Exploiting heterogeneity: Habitat use by cattle in dryland Zimbabwe. Journal of Arid Environments 29 (2): 221-237.

Scurlock, J.M.O., and D.O. Hall. 1998. The global carbon sink: A grassland perspective. Global Change Biology 4 (2): 229-233.

Smart, N.O.E., J.C. Hatton, and D.H.N. Spence. 1985. The effect of long-term exclusion of large herbivores on vegetation in Murchison Falls National Park, Uganda. Biological Conservation 33 (3): 229-245.

Stites, Elizabeth, Lorin Fries, and Darlington Akabwai. 2010. Foraging and fighting: Community perspectives on natural resources and conflict in Southern Karamoja. Medford: Feinstein International Center.

Stokes, C.J., Ryan R.J. McAllister, and Andrew J. Ash. 2006. Fragmentation of Australian rangelands: Processes, benefits and risks of changing patterns of land use. The Rangeland Journal 28 (2): 83-96.

Tilman, David, Peter Reich, Hope Phillips, Mary Menton, Ami Patel, Erin Vos, David Peterson, and J. Knops. 2000. Fire suppression and ecosystem carbon storage. Ecology 81 (10): 2680-2685.

Tosh, John. 1978. Lango agriculture during the early colonial period: Land and labour in a cash-crop economy1. The Journal of African History 19 (3): 415-439.

Turner, Matthew D. 2011. The new pastoral development paradigm: Engaging the realities of property institutions and livestock mobility in dryland Africa. Society and Natural Resources 24 (5): 469-484.

Turner, Matthew D., John G. McPeak, Kramer Gillin, Erin Kitchell, and Niwaeli Kimambo. 2016. Reconciling flexibility and tenure security for pastoral resources: The geography of transhumance networks in eastern Senegal. Human Ecology 44 (2): 199-215.

Turyahabwe, Nelson, and Abwoli Y. Banana. 2008. An overview of history and development of forest policy and legislation in Uganda. International Forestry Review 10 (4): 641-656.

UWA. 2013. Strategic plan 2013-2018. Uganda Wildlife Authority.

Weber, Keith T., and Shannon Horst. 2011. Desertification and livestock grazing: The roles of sedentarization, mobility and rest. Pastoralism: Research, Policy and Practice 1 (1): 19

Western, David, Victor N. Mose, Jeffrey Worden, and David Maitumo. 2015. Predicting extreme droughts in savannah Africa: A comparison of proxy and direct measures in detecting biomass fluctuations, trends and their causes. PLoS One 10 (8): e0136516.

Wigley, B.J., W.J. Bond, and M.T. Hoffman. 2009. Bush encroachment under three contrasting land-use practices in a mesic South African savanna. African Journal of Ecology 47 (s1): 62-70.

Wurzinger, Maria, Ali Mwai Okeyo, D. Semambo, and J. Souml. 2009. The sedentarisation process of the Bahima in Uganda: An emic view. African Journal of Agricultural Research 4 (11): 1154-1158.

Xie, Gaodi, Yili Zhang, Chunxia Lu, Du Zheng, and Shengkui Cheng. 2000. Study on valuation of rangeland ecosystem services of China. Journal of Natural Resources 16 (1): 47-53.

Yang, X., K. Zhang, B. Jia, and L. Ci. 2005. Desertification assessment in China: An overview. Journal of Arid Environments 63 (2): 517-531.

Zhuang, Minghao, and Wenjun Li. 2016. Market-based grazing land transfers and customary institutions in the management of rangelands: Two case studies on the Qinghai-Tibetan Plateau. Land Use Policy 57: 287-295.

Zziwa, Emmanuel, Geoffrey Kironchi, Charles Gachene, Swidiq Mugerwa, and Denis Mpairwe. 2012. The dynamics of land use and land cover change in Nakasongola district. Journal of Biodiversity and Environmental Sciences 2 (5): 61-73.

\section{Submit your manuscript to a SpringerOpen ${ }^{\circ}$ journal and benefit from:}

- Convenient online submission

- Rigorous peer review

- Open access: articles freely available online

- High visibility within the field

Retaining the copyright to your article

Submit your next manuscript at $>$ springeropen.com 